\title{
Understanding Prose Through Task Oriented Audio- Visual Activity: An American Modern Prose Course at the Faculty of Letters, Petra Christian University
}

\author{
Sarah Prasasti
}

\begin{abstract}
The method presented here provides the basis for a course in American prose for EFL students. Understanding and appreciation of American prose is a difficult task for the students because they come into contact with works that are full of cultural baggage and far apart from their own world. The audio visual aid is one of the alternatives to sensitize the students to the topic and the cultural background. Instead of proving the ready-made audio visual aids, teachers can involve students to actively engage in a more task oriented audiovisual project. Here, the teachers encourage their students to create their own audio visual aids using colors, pictures, sound and gestures as a point of initiation for further discussion. The students can use color that has become a strong element of fiction to help them calling up a forceful visual representation. Pictures can also stimulate the students to build their mental image. Sound and silence, which are a part of the fabric of literature, may also help them to increase the emotional impact.
\end{abstract}

Keywords: prose, audio visual aid, task oriented project, colors, pictures, sound, gestures, visual representation.

\section{Background}

As a lecturer of American Modern Prose at Petra Christian University, I find that there are two problems that may hinder my students from enjoying novels . Just like the other ESL students of literature, they generally find problems when undergoing " $\mathrm{a}$ two- stage learning process" (Honey, 1993:117) as they need to meet the clarification of the linguistic and cultural knowledge on the first stage before they can fully appreciate the text. The first problem is the limited level of linguistic competence of the students. They tend to spend a long time translating and working on detailed comprehension. As a result, they fail to look at the work selected as a whole, and thus, fail to enjoy it. The second problem, which becomes the focus of this paper, is the minimal level of cultural competence. I often find myself caught between the urgency to directly explain the cultural complication and the concern that a long lecture may hinder the students to enjoy the works. The way I see it is that the difficulties of Indonesian students to respond to foreign works of literature occur because they lack visual and aural environment. The distance of historical and geographical background becomes another burden for them. This kind of cultural gap becomes a blockage for the students to enjoy works of literature as a part of their life experience. 
The Indonesian students in my class, for example, feel altogether at a loss when reading Lee's To Kill a Mocking Bird. The problem is quite simple. Since there is no mockingbird in Indonesia, the students do not have any general knowledge of the bird, which gives the title its name. That is how they miss the symbolic importance of Atticus's advice to Scott, his nine-year old daughter: "Shoot all the bluejays you want if you can hit'em but remember it's a sin to kill a mocking bird"(Lee, 1975: 95,96). At the early chapters, they share the same confusion with Scott who, out of her innocence, also does not really understand what Atticus means. evertheless, they still fail to follow Scott's learning experiences of understanding the symbolic insight of the mocking bird. Scott finally understands that the mysterious Boo Radley, the children's subject of game, is just a harmless outcast. Bringing him to trial, she solemnly said, "would be sort of like shooting' a mockingbird, wouldn't it?" (1975: 280). However, as the outsiders of the culture, some of the students cannot follow Scott's train of thought in gaining understanding and grasping 'the mockingbird motif' of the work. It can be assumed, as Durant stated, that a fuller understanding of the text can only be gained with a clear picture of the cultural reference, especially if the originating culture is significant to interpret text with connotations or symbols (1993: 157).

Every page of a text carries a cultural baggage and thus, potentially brings misunderstanding. The students react differently toward these problems: some consciously ignored and some unconsciously misread them. Coming into contact with works inconceivably far apart from their environment, students have to face a different set of ethical/social concerns, customs, values, and also environment. Generally, the students have a lot of questions on what it seems to be "the basic information aspect" (Mayhead, 1981:38). As American literature has been produced within a cultural background far remote from the Indonesian students, a more interactive activity should be taken into consideration. Here the teachers have an important role in preparing and making them feel that the work they are reading is not so distant from the world he/she knows. Ideally, the teachers should bring the students into contact with the real situation. When this is not possible, the audio-visual aid may serve as one of the useful substitutes.

Audio-visual aids help students to build their mental image actively and feel American literature as a part of their life experience. Finding audio-visual aids for modern prose class is not difficult since there are many American novels that have been adapted to films and some are even recorded into cassettes. Films are certainly excellent audio-visual aid with all sound, picture, and motion combined. However, as we know it, in adapting the literary works for the screen, filmmakers have often interpreted the work differently from what the original authors might have intended. In my experience of using films in my class last semester, only a few numbers of exceptional students can critically comment on the inevitable changes of the film and able to keenly compare it with the work. They go back to the original text soon after that, realizing that it is only intended as a supplementary aid and not as a substitute of the work itself. Most students, however, just take the film for granted as the translation of the full text into the visual text, while some tend to treat the film passively as a shortcut to understand the novel easily and instantly.

In my opinion, a task-oriented audiovisual project is another alternative to encourage a more intense interaction between the students and the work discussed. Workshop methodology which usually takes the form of simulation, tasks and role play, as Alan Durant suggests, "offers types of involvement and satisfaction to students" (1993: 153). Hence, instead of using the ready-made videos, pictures, cassettes, and slides, we can 
encourage the students to be active participants by actively engaging in this task. Audio- visual task, in my opinion, may serve as a supplement in any methods of teaching literature and create a more interactive pedagogic approach.

\section{Theory}

Brumfit and Carter define the process of learning literature in two broad stages. The first stage enables students to "experience" literature, while the second enables them to describe or explain the experience (1986: 31). Serving more as a supplement, the audio-visual activity gives the students chance to experience the work and to raise the cultural awareness. Hence, it is aimed to help teachers awaken the students' cultural sensitivity. At the same time it is aimed to make the world of the novel more accessible for the EFL students. Soon after that, the students, this time equipped with a better cultural awareness, are expected to move forward to the second stage to be able to explain, analyze and appreciate the work.

Some outstanding students who tend to be diligent and "word smart" may work well in relating the far away world of the novel through words. However, some students who fail to understand the words need to "see" and "to hear" the cultural complication of the works. Hence, in some ways I also apply Howard Gardner's theory of multiple intelligences. Gardner identifies eight different kinds of intelligences, those are:

1. Verbal Linguistic (Word Smart)

2. Logical/Mathematical (Logic/Math Smart)

3. Bodily/Kinesthetic (Body Smart)

4. Naturalist (Nature Smart)

5. Visual/Spatial (Art/Space Smart)

6. Musical/Rhythmic (Music Smart)

7. Interpersonal (People Smart)

8. Intrapersonal (Self Smart)

I borrow some of his terms as the names of the tasks and apply the multiple intelligences theory in the students' activity through the multi ability tasks. Out of these eight intelligences, I apply four skills that cover: spatial (picture, color), musical (song, sound), verbal linguistic (playing with words) and kinesthetic (role-play, gesture) skills. By using different intelligences, we can have a more varied approach in the teaching and learning literature.

\section{Types of Task}

The types of task here are not exhaustive and the procedures are not prescriptive. Since not all types of task can suit all novels, any teacher can, of course, take the liberty of experimenting with or choosing the most suitable task and procedures. The tasks can be used at the beginning of the class as the warming-up activity or in the middle as the reinforcement of group discussion and as a point of initiation for critical comment. Below, I give some examples of the suggested tasks that I have already used in my class.

\section{Visual Task: color and picture}


Many authors use color and camera instruction as techniques to give a forceful visual representation. In fact color and pictorial or panoramic descriptions have been strong elements of fiction. Students can make good use of these techniques to visualize the setting, characters and figurative language. Students' pictures may vary from cut out pictures or sketches to artistic illustrations; from color charts to color paintings. As the students do this task, remind them not to stop on simply identifying the mood, the environment, the people or the object through their choice of colors and pictures. Stimulate them to analyze or to interpret" the image" that they want to reveal through their visualization.

\section{Examples of the works discussed}

\subsection{Edith Wharton's Ethan Frome}

Most of my students have no direct experience on the winter. That is why they need more time to understand Wharton's technique of using winter as the dominant setting and the symbolic imagery throughout the work. As modern readers, they also cannot imagine how winter makes the New England farmhouses in 1910s even more isolated and how snow and cold could cause benumbing suffering. Students cannot really understand how seasons have something to do with Ethan's regret of marrying Zeena after his mother died: "He had often thought since that it (the marriage) would not have happened if his mother had died in spring instead of winter..." (Wharton, 1970:30).

\section{$\underline{\text { Skill: }}$}

- To understand the motif and the imagery of winter in the novel

- To understand how and why winter affects the moods of the characters

- To understand how Wharton uses winter and spring symbolically to represent the two female characters, Zeena and Mattie.

\section{Task:}

- Ask students to find dominant colors in the novel.

Black (night) and white (the illuminating light of the snow) are obviously dominant

- Make a white chart big and clear enough to be seen properly by the whole class as the visualization of the season, winter, as well as the setting of the novel. A very low temperature in an air con class will be helpful. Invite the students to "see" and "sense" how bleak and cold the season is. Discuss how colorless the novel is meant to be.

- Ask them to find warm color in the text. A touch of red can only be found in Mattie's rosy cheeks and the red pickle dish. Ask them to make a little red chart.

- Ask them to contrast the two colors. Have them feel how these two colors refer to their sensation. Let them describe how white and red can set different moods.

- Discuss how Zeena personifies the season in appearance and behavior and how Mattie personifies the other season

- Put the little red chart in the middle of the huge white one. As the two colors are combined, discuss the dilemmatic circumstances that Ethan has to face.

\subsection{Steinbeck's Of Mice and Men}


In this novel, the readers can only find very few clues about the socio-economic backgrounds in 1930s. However, the novel abounds in character description, which will, certainly help keen readers to be able to have the picture of the social life in that era. To comprehend their close reading on the text, students can make illustration or find pictures that fit to their imagination on the fictional characters. Artistic expertise is not counted here. Students' attempt to put their "inner" pictures is more appreciated.

Skill:

- To understand the economic reality and the social classes in California in 1930s

- To understand and to have "sensory image" about the social life of ranch workers.

\section{$\underline{\text { Task }}$}

- Ask the students to do the close reading and denote physical appearance or qualities as well as their clothes. Have them set their imagination free to visualize the characters.

- Ask them to re-create the descriptive words in the text into pictures, make a simple illustration or find cut out pictures that come closest to the characters. Have them group their pictures based on their social classes.

- Let the students exchange their pictures and discuss them among themselves. Sometimes they question how their friends' pictures differ from the image of the characters they have had in mind. Usually they go back to text to confirm their visual interpretations. This activity can be used to prepare the students for the discussion on Steinbeck's concept of the middle class and the proletariat.

\section{Musical Task: sound and silence}

Some authors lavishly use silence and also sound such as symphonic and musical qualities and natural sounds to increase the emotional impact of the readers. Some authors also intentionally use musical themes as the backdrop of the work to convey the characters' feelings and emotions with few words.

Both sound and silence, as parts of the fabric of literature, help the students understand the mood and the atmosphere as well as the character's thought and feeling reflected in the work. Students may variously create a recorded sound, a sound montage (make sounds by voices and bodies), select a musical background or theme song.

\section{Examples of the works discussed}

\subsection{John Steinbeck's The Pearl}

The Pearl is just one of the many examples of literary works that significantly uses song. Throughout the story, the songs, the tradition of the Gulf people, run through the mind of Kino, the Mexican character. Here, songs serve more than just a musical background since they convey the Indians' thought and feeling. From the first chapter we know that the song represents "everything they saw or thought or did or heard" (Steinbeck,1971:7). Here, music replaces excess dialogue and description, and conveys the Indian's thought and feeling.

Skill: 
- To understand the Indian natural environment.

- To understand the Indians 'feeling and thought and reactions to their surrounding.

- To understand the function(s) that the songs perform.

Task:

- Ask the students to focus on the key sound that brings the image of the Indian natural environment. Ask them to create sound effect based on their close reading. They will find minor sounds send forth by animals such as the chatter of the birds, the crow of the rooster, the cry of coyotes, the screech of the owl etc. This task is aimed to give students the mental image of the closeness of the Indian to his natural world.

- Ask the students to select kinds of music that fit to the ones running through Kino's mind such as "the Song of the Family," "the Song of Evil," "the Song of the Pearl that Might Be," "the Song of the Enemy".

- Let the students explain how each of the song they have chosen reveals the basic emotion of the characters. By choosing their own music, students can imaginatively interpret the mental word picture that they find in the text to reveal their understanding of the overall tonality.

\subsection{Ernest Hemingway's A Farewell to Arm}

Despite his art of writing simple sentences, Hemingway writes works, which are rich of irony and highly suggestive. Before students get in touch with the climate of war in this canonized novel, a song under the same theme may help them to get closer to the flavor of the time.

Skill:

- To understand the romantic notions of young men in the First World War.

- To understand the tragic aftermath of war.

- To understand the mood of restless despair that the war brought.

Task:

- Use one section of the text as an introduction of the theme.

Ask the students to bring the song under the same group of theme. Encourage them to select songs with sociological depth or value.

- Ask them to bring in the lyrics of the song they like. Play the song and point out elements in the song that they expect to find in the work of the same theme.

- Use the song to be "the springboard" before discussing the novel. The interest aroused in this task is usually great and that by the end of the discussion the students have more eagerness to read the whole text.

\section{Verbal Linguistic Task: playing with words}

Students generally find problems in analyzing literary woks verbally. This difficulty is often marred their interest to make a written analysis. This task is packed in a more engaging but less stressful way as students are given chance to play with words. Below is an example of the verbal linguistic task in understanding the setting. 


\subsection{Faulkner's Absalom, Absalom!}

Many students have a hard time in enjoying Faulkner's works due to his technique of narration as well as his new forms and structures. Generally, they find Yoknapatawpha County, Faulkner's fictional setting, puzzling. They also need more time to understand Yoknapatawpha as an invented Southern society overlaying a real one. In this case, the combination of linguistic and cultural problems creates a serious blockage. To understand the importance of the imaginary setting of Faulkner's work, in this task, students are encouraged to make a travel brochure or instead of to make a written paper.

Skill:

- To understand the significance of apocryphal setting of Faulkner's short stories and novels, especially Absalom, Absalom!

- To understand the interlocking quality of Faulkner's works, such as the recurring characters and the allusions to other short stories or novels.

Task:

- Ask each student to search some clues or key words on the setting of place in Absalom, Absalom!

- Ask the students to conduct a short group discussion about the setting. Let them share their personal response on the place.

- Ask them to put the information of Yoknapatawpha County they have in a travel brochure. Have them express their emotional response on the place verbally. They may also use color, illustration or picture in their brochures. Tell them that the brochure should arouse the interest of the tourist. By engaging in this task they picture their own views about the place by reference to some clues in the text in words.

\section{Kinesthetic Task : Readers' Theater}

Reader's theater comes at the end of the audio-visual project. Students are encouraged to set "the film version" of the work. They can combine the whole tasks such as the color, picture, sound, words and gestures together to build a better understanding of the text.

Task:

- Ask students to select events from the text that they think would be suitable for adapting the role-play. Encourage them to rewrite the events they choose and set "the film" version of the book.

- Have them combine all of the tasks they have already completed.

- Invite the students to demonstrate understanding in detail.

\section{Conclusion}


With the help of audio-visual aid, the students can come closer to the world of the novel at other places and times. Through the tasks students can interpret the mental word picture through color, picture and sound and experience the imaginary world. Although the experience they have is, indeed, very simple, yet it is more immediate and likely to affect their thought and emotion since it appeals to the senses. The text becomes less troublesome for the students as it is no longer a distant imaginary work. As a learner-centered activity it also generates students' personal involvement in the learning process. In many ways it stimulates more interaction between student and student, teacher and student, and also student and the text itself. We can apply this kind of activity to as a tool to solve the problems of cultural and environmental differences, and at the same time as commitment to impart enjoyment for the students.

\section{References}

Brumfit, C.J and Carter, R.A. (1986). Literature and Language Teaching. Oxford, Oxford University Press.

Durant, Alan. (1993). "Interactive Approaches to Teaching Literature in Hong Kong" in Christopher Brumfit and Michel Benton (ed.), Teaching Literature: A World Perspective. London, Macmillan.

Faulkner, William. (1936). Absalom, Absalom!. New York, Random House.

Gardner, Howard. (1983). Frames of Mind: The Theory of Multiple Intelligence. New York, Basic Books.

Hemingway, Ernest. (1929). A Farewell to Arms. New York, Scribner.

Honey, John. (1993). "Examining Literature: an Alternative Curricular Perspective" in Christopher Brumfit (ed), Assessment in Literature Teaching. London, Macmillan.

Lee, Harper. (1975). To Kill a Mockingbird. London, Pan Books Ltd.

Mayhead, Robin. (1981). Understanding Literature. Great Britain, Cambridge University Press.

Steinbeck, John. (1953). The Short Novels of John Steinbeck. New York, Viking.

Steinbeck, John. (1975). The Pearl. London, Cox\&Wyman Books Ltd.

Wharton, Edith. (1970). Ethan Frome. New York, Charles Scribner's Sons, 